DOI https://doi.org/10.17308/vsu.proc.law.2021.1/3271

\title{
ОРГАНИЗАЦИЯ ИСПОЛНЕНИЯ НАЛОГОВОГО ОБЯЗАТЕЛЬСТВА
}

\author{
А. В. Красюков \\ Воронежский государственный университет \\ Поступила в редакцию 2 февраля 2021 г.
}

\begin{abstract}
Аннотация: статья посвящена изучению института организации исполнения налогового обязательства. Выделяются организаиионные налоговые правоотношения, обеспечиваюшие создание необходилых условий для исполнения налоговых обязательств, анализируется объект данных правоотношений. Основное внилание уделяется постановке налогоплательщиков на учет в налоговых органах, которую предлагается расслатривать в качестве механизма признания налоговой правосубъектности налогоплательщика. На основе проведенного исследования автор описывает и иные фбормы организационного взаимодействия налоговых органов и налогоплательщиков в процессе исполнения налогового обязательства.

Ключевые слова: налог, налоговое облзательство, организаиионное правоотношение, исполнение обязательства, правосубьектность, учет налогоплательщиков.
\end{abstract}

\begin{abstract}
: the article is devoted to the study of the institution of organizing the fulfillment of tax obligations. The author identifies organizational tax legal relations that ensure the creation of the necessary conditions for the fulfillment of tax obligations, and analyzes the object of these legal relations. The author focuses on the ruling of taxpayers to register with the tax authorities, which they are proposed to consider as a mechanism for recognizing the tax legal personality of a taxpayer. The author also describes other forms of organizational interaction between tax authorities and taxpayers in the process of fulfilling a tax obligation. Key words: tax, tax obligation, organizational legal relationship, fullfillment of obligation, legal personality, taxpayer accounting.
\end{abstract}

Исходя из содержания ст. 2 Налогового кодекса РФ (далее - НК РФ), предметом налогового права являются не только имущественные отношения, но и тесно связанные с ними неимущественные отношения, по сути, направленные на обеспечение возникновения, исполнения и прекращения налоговых обязательств.

Конституционный Суд РФ указал, что федеральное законодательство о налогах и сборах призвано создать надлежащие условия исполнения налоговой обязанности, в том числе определить систему налоговых органов, относящихся к фредеральным экономическим службам (п. «ж» ст. 71), их задачи, фрункции, формы и методы деятельности, порядок проверки правильности исчисления и своевременности уплаты (удержания и перечисления) налогов и сборов ${ }^{1}$.

${ }^{1}$ По жалобе открытого акционерного общества «Востоксибэлектросетьстрой» на нарушение конституционных прав и свобод положениями частей третьей и

(C) Красюков А. В., 2021 
Исходя из вышеуказанного, предметом исследования в настоящей статье избраны организационные налоговые правоотношения, обеспечивающие создание необходимых условий для исполнения налоговых обязательств. В рамках данных правоотношений центр активного поведения сосредоточен на стороне государства, поскольку для организации исполнения обязательства, основанного на законе, а не на добровольном соглашении сторон, требуются определенные властные полномочия.

Таким образом, государство в рамках организационных налоговых правоотношений среди прочего:

- определяет государственные органы, представляющие его интересы в налоговом обязательстве, и закрепляет их полномочия, формы и методы деятельности;

- закрепляет формы и методы осуществления налогового контроля;

- определяет правовой статус вспомогательных участников исполнения налогового обязательства (например, налоговый агент) и порядок реализации ими своих прав и обязанностей;

- определяет формы документов, используемых при исполнении налоговых обязательств, и реквизиты (другие данные), необходимые для исполнения налогового обязательства.

Иными словами, государство создает основу для надлежащего исполнения налогового обязательства. В юридической литературе подчеркивается, что обязанность уплачивать законно установленные налоги и сборы следует рассматривать в комплексе с обязанностями государства и государственных органов обеспечить надлежащие условия для уплаты налогов ${ }^{2}$.

Однако это не означает, что в рамках данных правоотношений организации и физические лица свободны от каких-либо обязанностей и ничего не предпринимают. В целях обеспечения условий для надлежащего исполнения налоговых обязательств частные субъекты (организации и ИП) обязаны встать на учет в налоговых органах.

В ст. 83 НК РФ указано, что учет налогоплательщиков осуществляется в целях налогового контроля. Представляется, что это не совсем так. Постановка на учет налогоплательщика в налоговом органе направлена:

1) на признание правосубъектности налогоплательщика или налого206 вого агента;

2) уточнение контрагента налогоплательщика в налоговом обязательстве (конкретного налогового органа):

- в целях определения реквизитов для уплаты налогов;

- в целях определения адресата для волеизъявления (подача заявлений, заключение соглашений и т. п.);

четвертой статьи 88, пункта 1 статьи 101 Налогового кодекса Российской Федерации и части 4 статьи 200 Арбитражного процессуального кодекса Российской Федерации : определение Конституционного Суда РФ от 12 июля 2006 г. № 267-О // Собр. законодательства Рос. Федерации. 2006. № 43. Ст. 4529.

${ }^{2}$ См.: Орлов М. Ю. Налог как форма разумного ограничения фискального суверенитета государства // Финансовое право. 2006. № 2. 
3) определение территориальных границ налогообложения, что оказывает влияние на обязательства по уплате региональных и местных налогов, а также федеральных налогов, зачисляемых в региональные и местные бюджеты.

Иными словами, постановка на учет налогоплательщика или налогового агента создает необходимые предпосылки для правильного определения элементов налогового обязательства и надлежащего его исполнения.

Постановка на учет в налоговом органе может быть направлена на признание как общей, так и спещиальной правосубъектности налогоплательщика.

\section{Постановка на учет как признание общей правосубъектности налогоплательщика}

Часть 4 ст. 171 предусматривает, что вычет или возврат НДС осуществляется иностранной организации при условии ее постановки на учет в налоговом органе. При этом постановка российских организаций на учет производится в момент их создания, т. е. государственной регистрации, а фризическим лицам по общему правилу требуется сделать волеизъявление для этого в прямой форме (заявление о постановке на учет) или косвенной (заявление о регистрации в качестве индивидуального предпринимателя). Автоматическая постановка на учет физических лиц в соответствии со ст. 84 НК РФ производится только при появлении у них имущества, признаваемого объектом налогообложения.

Такое отличие в постановке на учет обусловлено целями данного механизма, который ориентирован на создание условий для надлежащего исполнения налогового обязательства. Тем самым постановке на учет подлежит лицо, которое с высокой долей вероятности в ближайшем будущем станет налогоплательщиком, т. е. станет обладателем предмета налогообложения.

В отношении организаций, по-видимому, существует презумпция их вовлеченности в экономическую деятельность. Иными словами, если организация создается, то велика вероятность, что она начнет ту деятельность, для которой ее создали и станет в результате налогоплательщиком. Аналогичная презумпция существует в отношении индивидуальных предпринимателей и плательщиков налога на профрессиональный доход.

При этом следует различать первичную и вторичную постановку на учет налогоплательщика. Первичная постановка на учет производится по месту нахождения (жительства) налогоплательщика. Вторичная - по месту нахождения его имущества и обособленных подразделений. Вторичная постановка на учет производится в тех случаях, когда территория исполнения налогового обязательства оказывает или может оказать влияние на его условия или субъектный состав (например, нахождение на территории другого муниципального образования или субъекта РФ при уплате региональных и местных налогов). 
Деятельность же физических лиц, для которой отсутствует необходимость в специальной регистрации (например, работа по найму) либо не порождает значимых налоговых последствий, либо приводит к их участию в налоговых отношениях через налогового агента. При этом появление у физического лица налогооблагаемого имущества расценивается законодателем в качестве презумпции вступления в экономическую деятельность, требующую постановки на учет в налоговом органе без его волеизъявления (автоматически).

Для иностранных организаций постановка на учет в России всегда является вторичной. Однако в отличие от российских организаций вторичная постановка на учет иностранной организации представляет собой признание общей налоговой правосубъектности, отсутствие которой лишает такого налогоплательщика практически всех элементов налоговой дееспособности. Тем самым налоговое обязательство с участием таких иностранных организаций возникает лишь при наличии у них полностью дееспособного «представителя», а именно: постоянного представительства иностранной организации. При отсутствии постоянного представительства неполная дееспособность налогоплательщика - иностранной организации - замещается дееспособностью налогового агента, который рассматривается в качестве его представителя.

Отличительной особенностью некоторых иностранных организаций является возможность принудительного снятия их с учета в случае неисполнения налогового обязательства (п. 5.5 ст. 84 НК РФ). Иными словами, лишение полной налоговой дееспособности или ее ограничение, по сути, является специфической санкцией в отношении иностранной организации за неисполнение налогового обязательства в определенных законом случаях. Поскольку у иностранной организации постановка на учет в налоговом органе России всегда вторичная, то такое снятие не приводит к прекращению налоговой правосубъектности, но в значительной степени ограничивает налоговую дееспособность, что проявляется путем появления в структуре налогового обязательства налогового агента.

\section{Постановка на учет как признание специальной правосубъектности налогоплательщика}

208 Например, ст. 335 НК РФ предусматривает постановку налогоплательщика на учет в качестве плательщика налога на добычу полезных ископаемых. Иногда постановка налогоплательщика на учет подменяется регистрацией в налоговом органе объекта налогообложения. Так, ст. 366 НК РФ предусматривает регистрацию объектов игорного бизнеса вместо постановки на учет самого налогоплательщика. При этом и механизм такой регистрации, и набор документов, представляемых в налоговый орган, очень похожи на постановку на учет самого налогоплательщика.

Данная разновидность постановки на учет почти всегда связана с предоставлением налоговых льгот в той или иной форме. Например, постановка на учет в качестве налогоплательщика, применяющего патент- 
ную систему налогообложения (ст. 346. 46 НК РФ), по своей сути является завершающим юридическим фрактом в юридическом составе, предоставляющем право на применение льготного налогового режима.

При этом предоставление налоговой льготы может быть поставлено в зависимость от порядка постановки на учет: например, льгота по налогу на прибыль организаций и налогу на доходы фризических лиц предоставляется плательщику торгового сбора только при условии добровольной постановки на учет в налоговом органе (ст. 416 НК РФ).

Применительно к акцизам предоставление налоговых льгот производится не через постановку на учет, а посредством регистрации налогоплательщика в качестве лица, осуществляющего определенную деятельность (например, переработка прямогонного бензина).

Представляется, что во избежание путаницы в данных механизмах следует отделить механизм постановки на учет как фрормы признания общей правосубъектности от постановки на учет как фрормы признания специальной правосубъектности. В последнем случае предлагаем именовать этот механизм регистрацией налогоплательщиков, а не постановкой на учет.

Кроме постановки на учет в организационных налоговых правоотношениях налогоплательщики обязаны взаимодействовать с фискальными органами в целях обеспечения исполнения налогового обязательства при наличии различных препятствий этому. Так, в силу ч. 2.1 ст. 23 НК РФ налогоплательщик - физическое лицо - обязан представить в налоговый орган информацию о наличии у него недвижимого имущества или транспортных средств в случае неполучения им в установленные законом сроки первого налогового уведомления.

В соответствии с общими правилами налоговый орган должен получать данную информацию из других источников. Однако сбой в работе системы информационного обмена между государственными органами не должен воспрепятствовать надлежащему исполнению налогового обязательства. Поэтому добросовестный субъект налогового обязательства обязан вступить в информационное взаимодействие с налоговым органом в рамках организационного налогового правоотношения. Аналогично устроено взаимодействие налогоплательщика и налогового органа при участии налогоплательщика в составе других организаций, в том числе иностранных (например, уведомление об участии в контролируемых иностранных компаниях).

Существуют и иные формы информационного взаимодействия между налогоплательщиком и налоговым органом в рамках организационного правоотношения:

- уведомление о заключении операторского договора (п. 3 ст. 25.7 НК РФ);

- заявление о включении в реестр участников региональных инвестиционных проектов (ст. 25.11 НК РФ).

Все данные формы информационного взаимодействия направлены на создание условий для надлежащего исполнения налоговых обяза- 
тельств путем уведомления налогового или иного компетентного органа о значимых для данного обязательства юридических фрактах.

Таким образом, в рамках организационных налоговых правоотношений его сторонами создаются условия надлежащего исполнения налоговых обязательств:

- определяется правовой статус субъектов налогового обязательства;

- определяются территориальные границы налогового обязательства;

- определяется порядок исполнения обязательства (например, самостоятельно или через налогового агента);

- доводится информация о значимых для надлежащего исполнения налогового обязательства юридических фрактах.

Воронежский государственньй университет

Красюков А. В., кандидат юридических наук, дочент кафедры фбинансового права

E-mail:kav@law.vsu.ru
Voronezh State University

Krasyukov A. V., Candidate of Legal Sciences, Associate Professor of the Financial Law Department

E-mail:kav@law.vsu.ru 